\title{
Effects of Pythium Species and Time in Cold Storage on the Survival of Bareroot and Container-Grown Southern Pine Seedlings
}

\author{
D. Paul Jackson, Scott A. Enebak, and David B. South \\ School of Forestry and Wildlife Sciences, Auburn University, 602 Duncan Drive, Al 36849, USA \\ Correspondence should be addressed to D. Paul Jackson, paul.jackson@auburn.edu
}

Received 20 January 2012; Accepted 15 February 2012

Academic Editor: F. Berninger

Copyright ( 2012 D. Paul Jackson et al. This is an open access article distributed under the Creative Commons Attribution License, which permits unrestricted use, distribution, and reproduction in any medium, provided the original work is properly cited.

Cold storing bareroot southern pine (Pinus spp.) seedlings for greater than one week after lifting in the fall can lead to poor outplanting survival when compared to seedlings that are lifted and stored in winter. In contrast, container-grown seedlings typically do not experience adverse effects from storing for periods greater than one week. The practice of lifting bareroot seedlings can cause wounds to root systems, which could allow soil-borne pathogens such as Pythium species to be used as infection sites. Once seedlings are placed in storage, the cool, moist environment may be conducive for zoospore activity, leading to root disease and outplanting failure. Bareroot and container-grown longleaf pine (Pinus palustris), loblolly pine (Pinus taeda), and slash pine (Pinus elliottii) and container-grown shortleaf pine (Pinus echinata) were inoculated with either Pythium dimorphum or Pythium irregulare, coldstored for 3, 4, 6, or 12 weeks, and outplanted. Both Pythium species reduced survival of bareroot longleaf pine but not bareroot slash pine. Length of storage decreased survival for both seedling stock types. Pythium species did not affect the survival of container-grown seedlings. These results suggest that $P$. dimorphum and $P$. irregulare are more virulent to bareroot longleaf pine than the other pine species tested.

\section{Introduction}

In the southern USA, forest tree nursery managers commonly hold pine (Pinus spp.) seedlings in cold storage $\left(<5^{\circ} \mathrm{C}\right)$ after lifting when transplanting operations are stopped due to adverse weather. Bareroot seedlings lifted and held in longterm cold storage ( $>1 \mathrm{wk})$ in the fall (before the winter solstice) can result in poor seedling survival compared to when seedlings are lifted and stored during winter months. For example, Kahler and Gilmore [1] reported loblolly pine (Pinus taeda) seedling survival to be less than $60 \%$ when lifted and cold-stored in the fall and greater than $90 \%$ when lifted and cold-stored after the winter solstice. In another study, loblolly pine seedlings lifted in the fall and stored for two weeks had less than $3 \%$ survival, while survival without storage ranged between 66 and 92\% [2].

Two theories exist to explain why bareroot pine seedling survival is poor following lifting and cold storage during the fall season. The first theory involves the lifting of seedlings that have nondormant buds or that have not been exposed to a certain number of chilling hours. Chilling hours is defined as the exposure of seedlings to above-freezing temperatures $\left(<8^{\circ} \mathrm{C}\right)$ for a specific period of time, and after this time period, seedling buds may be classified as dormant [3]. Carlson [4] claimed that successful cold storage was dependent on meeting a chilling hour requirement and seedlings having dormant buds, which is why seedlings are generally "hot planted" and not stored. Boyer and South [5] and Pickens [6] reported that periods of cold storage were possible for container-grown pine seedlings during the fall without the required number of chilling hours. Container-grown seedlings generally do not experience the adverse effects (poor survival) from long-term storage during the fall, which suggests that successful seedling survival after cold storage may not be directly related to either chilling hours or bud dormancy.

The second theory for the difference in survival between bareroot and container-grown seedlings may be related to root system damage. As container-grown seedlings are 
extracted, seedling roots remain intact within a plug of organic media, whereas bareroot seedling roots can be wounded during lifting from nursery beds. These wounds could then serve as infection sites for soil-borne pathogens. Studies have shown that applying fungicides to seedling roots prior to storage can increase seedling survival after outplanting [7, 8]. In these trials, Pythium populations from seedling roots increased over time in cold storage, but Pythium levels decreased on seedlings when benomyl, metalaxyl, or combinations of each fungicide were added. In a another study, Sun [9] inoculated longleaf pine (Pinus palustris) with increasing levels of Pythium dimorphum Hendrix and Campbell, which resulted in increases in seedling mortality after storage. This may have been the first study to show that a Pythium species could kill cold-stored bareroot pine seedlings after outplanting.

Pythium is an oomycetous pathogen commonly found in nursery soils and is associated with "damping-off" of seed and emerging germinants and "fine feeder root disease" in older seedlings [10]. Classified as a "water mold," Pythium zoospore activity increases in high moisture conditions such as in seedling storage bags [11]. After lifting, seedlings are sprayed with a combination of superabsorbent gel and water to prevent desiccation in bags [3]. Excess water can pool in seedling bags and, along with cool storage temperatures $\left(1^{\circ}\right.$ to $\left.5^{\circ} \mathrm{C}\right)$, may allow an ideal environment for Pythium zoospores to thrive and multiply. Once established on roots, Pythium could cause seedling mortality after outplanting.

The aim of these studies was to expand on Sun's study to see if $P$. dimorphum and a more common species, Pythium irregulare Buisman, could kill bareroot and container-grown pine seedlings after cold storage. Hendrix and Campbell [12] were the first to describe Pythium dimorphum, which was isolated from loblolly pine feeder roots in southwest Louisiana and, since, has been isolated by Ho [13] and Asiegbu and others [14]. Pythium irregulare is not known as a storage pathogen but was selected based on being one of the most common damping-off pathogen in nurseries [11] and also to serve as a baseline for comparison to $P$. dimorphum. It was first discovered on pea roots and cucumber seeds in The Netherlands [15] and has also been associated with outplanting mortality of Mexican weeping pine (Pinus patula) seedlings in South Africa [16]. Pythium irregulare might have also been associated with the decline of loblolly pine stands in Louisiana [17]. The objectives of these studies were to (1) test the effects of Pythium and time in cold storage on survival of bareroot and container-grown loblolly, longleaf, and slash pine (Pinus elliottii) and container-grown shortleaf pine (Pinus echinata) seedlings and (2) to quantify Pythiaceous populations from seedling roots in cold storage. To date, the null hypothesis (i.e., no effect on survival of stored seedlings) has not been rejected for any pathogen other than Pythium species.

\section{Materials and Methods}

2.1. Inoculum Preparation. Pythium dimorphum (ATCC 22843) and Pythium irregulare (ATCC 10951) were obtained from American Type Culture Collection (ATCC, Manassas, VA). Both Pythium species were aseptically transferred to oatmeal agar [18]. From the advancing margin of the mycelium, three $0.5 \mathrm{~cm}$ disks of each Pythium spp. were again transferred to additional oatmeal agar plates to eventually be used as inoculum. Prior to inoculation, $1.190 \mathrm{~g}$ of oatmeal and $400 \mathrm{~mL}$ of distilled water were combined in two autoclavable bags, mixed thoroughly, and autoclaved. The sterilized oats were allowed to cool for 24 hours and one autoclaved oatmeal bag received three plates of $P$. dimorphum and the other bag received three plates of $P$. irregulare. The oatmealPythium inoculum was mixed every 12 hours and stored at room temperature for 10 days prior to seedling root inoculations.

2.2. Seedling Inoculations. Two separate experiments were conducted using 8-month-old: (1) bareroot and containergrown longleaf pine (2008) and (2) bareroot and containergrown loblolly and slash pine and container-grown shortleaf pine (2009). Bareroot seedlings were obtained from SmurfitStone Corporation's Rock Creek Nursery near Brewton, AL, and container-grown seedlings from International Forest Company in Moultrie, GA, in December 2007. Prior to inoculations, bareroot and container-grown pine seedlings remained in cold storage $\left(4-5^{\circ} \mathrm{C}\right)$ for 6 and 8 days, respectively. Inoculum preparation, seedling inoculation, seedling outplanting, and data collection methods were similar in both study years. Bareroot longleaf pine (2008) and loblolly and slash pine (2009) seedlings were treated with one of seven treatments: $0 \mathrm{~g}, 50 \mathrm{~g}, 100 \mathrm{~g}$, and $200 \mathrm{~g}$ of $P$. dimorphum oatmeal inoculum, $0 \mathrm{~g}, 50 \mathrm{~g}, 100 \mathrm{~g}$, and $200 \mathrm{~g}$ of $P$. irregulare oatmeal inoculum. Longleaf pine seedlings were inoculated on December 14 (2008 study) and loblolly and slash seedlings on December 18 (2009 study). Inoculations began by weighing out the desired treatment amount of oatmeal inoculum on a scale and mixing in 11 liters of water. Treated seedlings remained immersed in the bucket of inoculum for approximately 5 seconds. Noninoculated seedlings (controls) were dipped into a bucket of water without inoculum. After each seedling replication was inoculated, buckets were emptied, rinsed, and filled with a new oatmeal inoculum mixture. Inoculated seedlings were placed in 49-liter plastic bags and put in cold storage $\left(4-5^{\circ} \mathrm{C}\right)$ for 3,6 , and 12 weeks (2008) and 4, 6, and 12 weeks (2009). Three replications of each treatment were used for bareroot longleaf in 2008 (30 seedlings/rep) and bareroot loblolly and slash pine in 2009 (20 seedlings/rep).

Container-grown longleaf pine (2008) and loblolly, slash, and shortleaf pine (2009) received one of five treatments: $200 \mathrm{~g}$ of $P$. dimorphum oatmeal inoculum with and without root wounding, $200 \mathrm{~g}$ of $P$. irregulare oatmeal inoculum with and without root wounding, and noninoculated seedlings received neither inoculum nor root wounding. Wounding was done by cutting down two sides of the container root plug with a knife in order to simulate wounding of bareroot seedlings at lifting. Three replications of each treatment were used for container-grown longleaf (30 seedlings/rep) in 2008; loblolly and slash (20 seedlings/rep) and shortleaf pine ( 15 seedlings/rep) in 2009. 
2.3. Seedling Survival. After each storage period, seedlings were outplanted into sand in a completely randomized block design at $0.3 \times 0.3 \mathrm{~m}$ spacing near Auburn University. Each block represented $17 \mathrm{~m}^{2}$ of planting area with 1,890 bareroot and 1,350 container-grown longleaf pine seedlings outplanted in 2008. In 2009, 1,260 bareroot and 900 container-grown each of loblolly and slash pine and 675 container-grown shortleaf pine seedlings were outplanted. Seedling survival was monitored for 6 months, and a seedling was considered dead when foliage was no longer green.

2.4. Pythiaceous Populations. To quantify Pythiaceous colonization following storage, roots from three random, live seedlings in each replication/treatment of each stock type were assayed after each storage period. After rinsing soil from the roots, lateral roots and fine feeder roots $(5 \mathrm{~cm}$ from the taproot) were removed from seedlings. Root subsamples were surface-sterilized in a $10 \%$ bleach solution and rinsed two times in sterile, distilled water. After sterilization, ten $2.5 \mathrm{~cm}$ root segments were randomly chosen and placed onto a plate of selective media for Pythiaceous species [19]. Each replication of loblolly, slash, and shortleaf pine had a total of $25 \mathrm{~cm}$ of roots on one agar plate. Colony-forming units (CFUs) that recovered onto selective media were counted and only considered "Pythiaceous" due to being on selective media for Pythium species and by mycelia comparison to know Pythium isolates.

2.5. Statistical Analyses. Statistical analyses were conducted using a General Linear Model (GLM) in SAS statistical software (9th ed., SAS Institute, Cary, NC). An experimental unit consisted of the 30 longleaf, 20 loblolly and slash, or 15 shortleaf pine seedlings that were dipped into the bucket of inoculum. Means of each experimental unit for each dependant variable were analyzed using Analysis of Variance (ANOVA) in a factorial design $(\alpha=0.05)$. Data for bareroot and container-grown longleaf pine in 2008 and bareroot loblolly and slash pine in 2009 were analyzed separately (by stock type and pine species), and contrast analyses were performed using combined levels of each Pythium treatment. Data for container-grown loblolly, slash, and shortleaf pine in 2009 were analyzed together.

\section{Results}

3.1. Bareroot and Container-Grown Longleaf Pine (2008). Inoculating bareroot longleaf pine roots with either $P$. dimorphum or $P$. irregulare prior to cold storage reduced longleaf pine survival (Table 1). Noninoculated longleaf pine survival was low (24\%) but was higher than any other treatment when all storage periods were combined (Table 2). Time in storage reduced bareroot longleaf pine survival after outplanting with Pythium-inoculated seedling survival at $12 \%$ at 3 weeks and $3 \%$ at 12 weeks (Table 2). Noninoculated bareroot seedling survival at 3 and 12 weeks was $34 \%$ and $22 \%$, respectively.

Neither inoculation with Pythium spp. nor root wounding of container-grown longleaf pine roots affected seedling survival after storage and outplanting. Storage length did
TABLe 1: Analysis of variance for bareroot longleaf pine seedling survival in 2008.

\begin{tabular}{lcc}
\hline & DF & $\begin{array}{c}\text { P }>\text { F } \\
\text { Survival (\%) }\end{array}$ \\
\hline Replication & 2 & 0.7257 \\
Treatment & 6 & 0.0018 \\
Storage & 2 & 0.0098 \\
Treatment $*$ storage & 12 & 0.9766 \\
Control versus P. dimorphum & 1 & 0.0001 \\
Control versus P. irregulare & 1 & 0.0001 \\
P. dimorphum versus P. irregular & 1 & 0.5806 \\
Error & 40 & \\
\hline
\end{tabular}

TABLE 2: Mean bareroot longleaf pine survival for 3- 6- and 12-week stored $\left(4-5^{\circ} \mathrm{C}\right)$ seedlings six months after outplanting in 2008 .

\begin{tabular}{lcccc}
\hline Treatment $^{\mathrm{z}}$ & \multicolumn{4}{c}{ Survival (\%) } \\
& 3 wks & 6 wks & 12 wks & Total \\
\hline Control & 34 & 15 & 22 & 24 \\
P. dimorphum 50 g & 13 & 12 & 4 & 10 \\
P. dimorphum 100 g & 11 & 2 & 2 & 5 \\
P. dimorphum 200 g & 6 & 2 & 3 & 4 \\
P. irregulare 50 g & 14 & 4 & 6 & 8 \\
P. irregulare 100 g & 16 & 8 & 3 & 9 \\
P. irregulare 200 g & 11 & 4 & 3 & 6 \\
LSD & $(25)$ & $(12)$ & $(13)$ & $(9)$ \\
\hline
\end{tabular}

${ }^{2}$ Pythium inoculation treatments took place on December 17, 2007.

${ }^{y}$ Least significant difference $(\alpha=0.05)$.

TABLE 3: Mean container-grown longleaf pine survival for 3- 6- and 12 -week stored $\left(4-5^{\circ} \mathrm{C}\right)$ seedlings six months after outplanting in 2008 .

\begin{tabular}{lcccc}
\hline Treatment $^{\mathrm{z}}$ & \multicolumn{4}{c}{ Survival (\%) } \\
& 3 wks & $6 \mathrm{wks}$ & $12 \mathrm{wks}$ & Total \\
\hline Control, no wounding & 93 & 98 & 68 & 86 \\
P. dimorphum 200 g, no wounding & 93 & 98 & 72 & 88 \\
P. dimorphum 200 g, wounding & 98 & 91 & 71 & 87 \\
P. irregular 200 g, no wounding & 98 & 92 & 74 & 88 \\
P. irregulare 200 g, wounding & 96 & 99 & 78 & 91 \\
LSD $^{y}$ & $(5)$ & $(10)$ & $(19)$ & $(9)$ \\
\hline
\end{tabular}

${ }^{2}$ Pythium inoculation treatments took place on December 17, 2007.

y Least significant difference $(\alpha=0.05)$.

reduce container-grown seedling survival $(P=0.0001)$ as seedling survival for all treatments was $96 \%$ at 6 weeks but decreased to $73 \%$ at 12 weeks of storage (Table 3). Overall, bareroot longleaf pine survival was $<25 \%$ for all treatments (Table 2), whereas container-grown longleaf pine survival was $>85 \%$ for all treatments (Table 3 ). Pythium populations in 2008 were not quantified from bareroot or containergrown longleaf pine roots.

3.2. Bareroot Loblolly Pine (2009). When the three inoculum levels were combined for each Pythium spp., bareroot loblolly pine survival was not affected by either $P$. dimorphum or 
TABLE 4: Analysis of variance for bareroot loblolly and slash pine seedling survival and Pythiaceous colony-forming units in 2009.

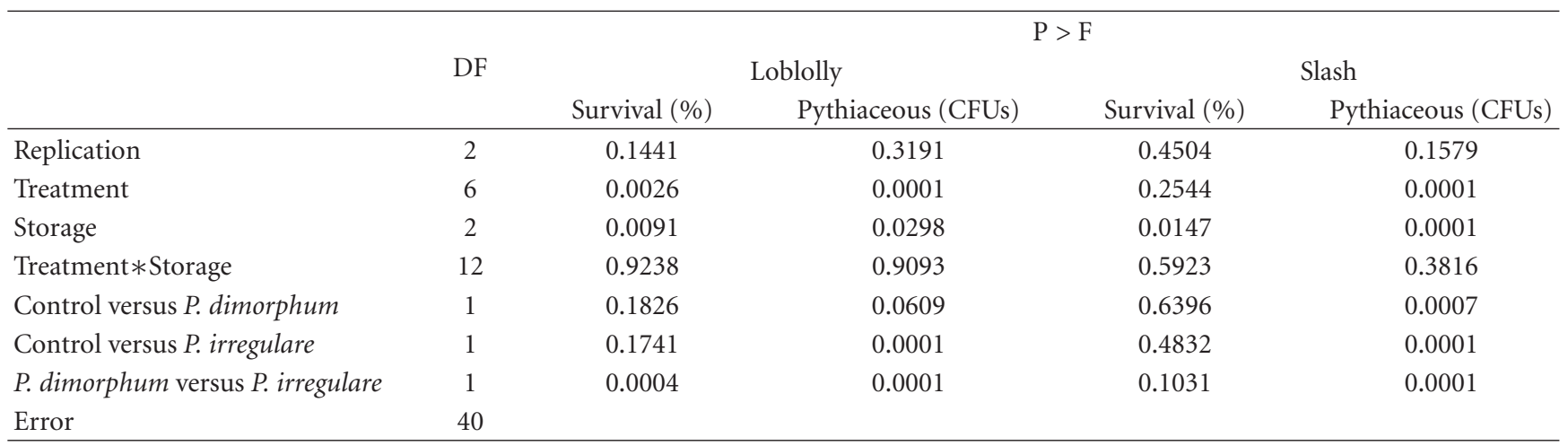

TABle 5: Mean bareroot loblolly and slash pine survival and Pythiaceous colony-forming units (CFUs) for 4- 6- and 12-week stored (4-5 ${ }^{\circ}$ ) seedlings six months after outplanting in 2009.

\begin{tabular}{|c|c|c|c|c|c|c|c|c|c|}
\hline \multirow{2}{*}{ Pine } & \multirow{2}{*}{ Treatment $^{\mathrm{z}}$} & \multicolumn{4}{|c|}{ Survival (\%) } & \multicolumn{4}{|c|}{ Pythiaceous (CFUs) } \\
\hline & & $4 \mathrm{wks}$ & $6 \mathrm{wks}$ & 12 wks & Total & $4 \mathrm{wks}$ & 6 wks & $12 \mathrm{wks}$ & Total \\
\hline \multirow{8}{*}{ Loblolly } & Control & 42 & 37 & 37 & 38 & 0 & 0 & 0 & 0 \\
\hline & P. dimorphum $50 \mathrm{~g}$ & 70 & 42 & 60 & 57 & 0 & 2.6 & 4.3 & 2.3 \\
\hline & P. dimorphum $100 \mathrm{~g}$ & 57 & 38 & 33 & 43 & 0 & 4.3 & 10.6 & 5 \\
\hline & P. dimorphum $200 \mathrm{~g}$ & 48 & 43 & 35 & 42 & 0 & 4.6 & 4 & 2.8 \\
\hline & P. irregulare $50 \mathrm{~g}$ & 52 & 37 & 28 & 39 & 6.3 & 8 & 8.3 & 7.5 \\
\hline & P. irregulare $100 \mathrm{~g}$ & 25 & 12 & 23 & 20 & 7.6 & 11.6 & 10.3 & 9.8 \\
\hline & P. irregulare $200 \mathrm{~g}$ & 45 & 22 & 18 & 28 & 11.6 & 14.3 & 14.3 & 13.4 \\
\hline & $\mathrm{LSD}^{\mathrm{y}}$ & (33) & $(31)$ & (28) & (16) & $(5.0)$ & $(9.0)$ & $(10.1)$ & $(4.3)$ \\
\hline \multirow{8}{*}{ Slash } & Control & 72 & 52 & 40 & 54 & 0 & 0 & 1.3 & 0.4 \\
\hline & P. dimorphum $50 \mathrm{~g}$ & 83 & 60 & 40 & 61 & 2.3 & 7.3 & 18.6 & 9.4 \\
\hline & P. dimorphum $100 \mathrm{~g}$ & 92 & 60 & 50 & 67 & 2.6 & 2.3 & 16 & 7 \\
\hline & P. dimorphum $200 \mathrm{~g}$ & 42 & 45 & 52 & 46 & 6 & 8.3 & 18.6 & 11 \\
\hline & P. irregulare $50 \mathrm{~g}$ & 53 & 40 & 50 & 48 & 4.3 & 15.6 & 17.3 & 12.4 \\
\hline & P. irregulare $100 \mathrm{~g}$ & 58 & 43 & 53 & 52 & 20 & 23 & 26.6 & 24.3 \\
\hline & P. irregulare $200 \mathrm{~g}$ & 53 & 42 & 47 & 47 & 21 & 20 & 24 & 21.6 \\
\hline & $\mathrm{LSD}^{\mathrm{y}}$ & $(25)$ & (36) & (43) & (19) & $(7.0)$ & $(12.4)$ & $(13.2)$ & (4.6) \\
\hline
\end{tabular}

${ }^{\mathrm{z}}$ Pythium inoculation treatments took place on December 18, 2008.

${ }^{y}$ Least significant difference $(\alpha=0.05)$.

P. irregulare when contrasted against noninoculated (control) seedlings (Table 4). However, seedlings treated with $100 \mathrm{~g}$ of $P$. irregulare oatmeal inoculum decreased seedling survival (LSD $=16$ ) (Table 5). Loblolly pine treated with $P$. irregulare oatmeal inoculum decreased seedling survival when contrasted against those inoculated with $P$. dimorphum $(P=0.0004)$ (Table 5). Time in storage also decreased loblolly pine survival (Table 4). After 4 weeks of storage, noninoculated loblolly pine survival was $42 \%$, compared to $37 \%$ at 12 weeks (Table 5). Loblolly pine survival after 4 weeks of storage for seedlings inoculated with $P$. dimorphum and $P$. irregulare was $58 \%$ and $41 \%$, respectively, compared to $43 \%$ and $23 \%$ at 12 weeks.

Higher levels of Pythiaceous (CFUs) were recovered from bareroot loblolly pine inoculated with $P$. irregulare than those inoculated with P. dimorphum (Table 5). Generally, the number of Pythiaceous CFUs recovered from $P$. irregulareinoculated loblolly pine increased as the inoculum level increased (Table 5). Pythiaceous CFUs were not recovered from $P$. dimorphum-inoculated loblolly pine until 6 weeks in storage with an average of 6 CFUs recovered by 12 weeks (Table 5). In contrast, $P$. irregulare treatments had an average of 8 Pythiaceous CFUs by week 4 and 11 CFUs after 12 weeks. Pythiaceous CFUs were not recovered from any of the noninoculated seedlings.

3.3. Bareroot Slash Pine (2009). Inoculation of bareroot slash pine seedlings with Pythium spp. did not affect seedling survival after storage and outplanting (Table 5). However, seedling survival decreased as seedlings remained in storage to 12 weeks $(P=0.0147)$. After 4 weeks, $P$. dimorphum and $P$. irregulare-inoculated slash pine had $72 \%$ and $55 \%$ survival, respectively, which was similar to noninoculated seedlings $(72 \%)$. The decrease in survival for seedlings inoculated with $P$. dimorphum was greater than for $P$. irregulare between 4 and 
TABLE 6: Mean container-grown loblolly, slash, and shortleaf pine survival and Pythiaceous colony-forming units (CFUs) for 4- 6- and 12 -week stored $\left(4-5^{\circ} \mathrm{C}\right)$ seedlings six months after outplanting in 2009.

\begin{tabular}{|c|c|c|c|c|c|c|c|c|c|}
\hline \multirow{2}{*}{ Pine } & \multirow{2}{*}{ Treatment $^{2}$} & \multicolumn{4}{|c|}{ Survival (\%) } & \multicolumn{4}{|c|}{ Pythiaceous CFUs } \\
\hline & & 4 wks & 6 wks & 12 wks & Total & 4 wks & 6 wks & 12 wks & Total \\
\hline \multirow{6}{*}{ Loblolly } & Control, no wounding & 82 & 72 & 5 & 53 & 0 & 0 & 0 & 0 \\
\hline & P. dimorphum $200 \mathrm{~g}$, no wounding & 93 & 62 & 5 & 53 & 0 & 0 & 0 & 0 \\
\hline & P. dimorphum $200 \mathrm{~g}$, wounding & 87 & 65 & 2 & 51 & 0 & 0 & 1.3 & 0.4 \\
\hline & P. irregular $200 \mathrm{~g}$, no wounding & 88 & 82 & 10 & 60 & 0 & 0 & 0.6 & 0.2 \\
\hline & P. irregulare $200 \mathrm{~g}$, wounding & 92 & 67 & 7 & 55 & 2.6 & 3.6 & 6.6 & 4.3 \\
\hline & $\mathrm{LSD}^{\mathrm{y}}$ & $(12)$ & $(37)$ & (5) & $(37)$ & $(2.0)$ & $(3.7)$ & $(3.5)$ & $(1.7)$ \\
\hline \multirow{6}{*}{ Slash } & Control, no wounding & 72 & 72 & 5 & 50 & 0 & 0 & 0 & 0 \\
\hline & P. dimorphum $200 \mathrm{~g}$, no wounding & 87 & 75 & 7 & 56 & 0 & 0.3 & 0 & 0.1 \\
\hline & P. dimorphum $200 \mathrm{~g}$, wounding & 77 & 70 & 15 & 54 & 0 & 0 & 0 & 0 \\
\hline & P. irregular $200 \mathrm{~g}$, no wounding & 85 & 78 & 5 & 56 & 2 & 3 & 3.3 & 2.8 \\
\hline & P. irregulare $200 \mathrm{~g}$, wounding & 95 & 73 & 7 & 58 & 2.6 & 7.6 & 6.6 & 5.6 \\
\hline & LSD $^{\mathrm{y}}$ & $(15)$ & $(16)$ & $(13)$ & $(35)$ & $(2.5)$ & $(6.6)$ & $(3.1)$ & $(2.3)$ \\
\hline \multirow{6}{*}{ Shortleaf } & Control, no wounding & 78 & 87 & 4 & 56 & 0 & 0 & 0 & 0 \\
\hline & P. dimorphum $200 \mathrm{~g}$, no wounding & 78 & 82 & 2 & 50 & 2.3 & 1.6 & 2.3 & 2.1 \\
\hline & P. dimorphum $200 \mathrm{~g}$, wounding & 89 & 58 & 2 & 50 & 3.3 & 2.6 & 3 & 8.9 \\
\hline & P. irregulare $200 \mathrm{~g}$, no wounding & 93 & 80 & 2 & 58 & 5.3 & 4.6 & 7.3 & 5.7 \\
\hline & P. irregulare $200 \mathrm{~g}$, wounding & 82 & 58 & 9 & 50 & 6 & 8 & 4.6 & 6.2 \\
\hline & $\mathrm{LSD}^{\mathrm{y}}$ & $(24)$ & $(35)$ & $(12)$ & $(38)$ & $(4.2)$ & $(5.0)$ & $(2.0)$ & $(2.0)$ \\
\hline
\end{tabular}

${ }^{\mathrm{z}}$ Pythium inoculation treatments took place on December 19, 2008.

$\mathrm{y}$ Least significant difference $(\alpha=0.05)$.

12 weeks of storage. However, at 12 weeks of storage, seedling survival was similar for all Pythium treatments.

Inoculated slash pine had more Pythiaceous CFUs recovered from their roots than noninoculated seedlings (Table 5). Higher levels of Pythiaceous CFUs were recovered from $P$. irregulare-inoculated seedling roots than from those inoculated with $P$. dimorphum when $100 \mathrm{~g}$ or $200 \mathrm{~g}$ of inoculum was used $(P=0.0001)$. Pythium recovery levels increased with storage length with $P$. dimorphum-inoculated slash pine having 4 CFUs compared to 15 CFUs for $P$. irregulareinoculated seedlings at 4 weeks (Table 5).

3.4. Container-Grown Loblolly, Slash, and Shortleaf Pine (2009). Inoculation of seedling roots with Pythium did not affect seedling survival $(P=0.2416)$, but storage length and root wounding interacted to reduce seedling survival $(P=$ 0.0311 ). Seedling survival was $87 \%$ for both wounded and nonwounded inoculated seedlings at 4 weeks but decreased to $6 \%$ at week 12 (Table 6). Container-grown loblolly, slash, and shortleaf pine had 54\%, 55\%, and 54\% survival, respectively, for all treatments. Container-grown loblolly and slash pine inoculated with $P$. irregulare had higher numbers of Pythiaceous CFUs recovered from their roots than noninoculated seedlings (Table 6). The highest number of Pythiaceous CFUs was recovered from wounded roots of shortleaf pine inoculated with $P$. dimorphum (Table 6).

\section{Discussion}

4.1. Bareroot Seedlings. Inoculating bareroot longleaf pine seedlings with either $P$. dimorphum or $P$. irregulare before storage reduced seedling survival to less than $11 \%$ for all inoculum levels after 12 weeks. Sun [9] reported a similar decrease in bareroot longleaf pine survival after inoculating seedlings with $P$. dimorphum and 4 weeks of storage. His study, along with these results, is the only reports that show decreases in longleaf pine seedling survival after inoculation with Pythium species. Another study reported bareroot longleaf pine survival to be $30 \%$ after 6 weeks of storage when roots were treated with clay, compared to $55 \%$ for seedlings with benomyl-treated roots [7]. In their study, Pythium species was isolated in high numbers from longleaf pine roots that did not receive benomyl. Our results are the first to show reductions in bareroot longleaf pine survival after inoculations with $P$. irregulare.

Sun [9] also reported similar seedling survival for stored (95\%) and nonstored (96\%) longleaf pine which were not inoculated with Pythium. For this reason, we did not include a noninoculated, nonstored treatment in our studies. In hindsight, this information may have assisted in explaining whether poor noninoculated bareroot longleaf pine survival (24\%) was due to either adverse environmental conditions at the planting site or long-term storage effects.

Based on seedling survival, inoculations with $P$. irregulare caused more virulence to loblolly pine when compared to P. dimorphum. In addition, more Pythiaceous CFUs were recovered from seedlings inoculated with $P$. irregulare than with $P$. dimorphum and the number increased as the level of inoculum and time in storage increased. Colony-forming units were only identified as Pythiaceous by being on selective media for Pythium species and by comparison to known $P$. dimorphum and P. irregulare isolates. Without formal identification of CFUs to species, a direct correlation between 
P. irregulare and P. dimorphum and seedling mortality cannot be made. However, the recovery of Pythiaceous CFUs suggests that Pythiaceous species can survive in cold storage on seedling roots. In other studies, more Pythium was recovered from longleaf pine roots that did not receive benomyl or metalaxyl treatment prior to storage [8], and this data suggests the fungicides controlled soil-borne pathogens that may have been present on the roots.

The distribution of soil-borne pathogens in the nursery is dependent upon many factors [20]. In response to the environment, Pythium zoospores can become active from their saprophytic state in the soil around areas of high root exudation or moisture [11]. Lateral root pruning and undercutting are common nursery practices prior to lifting (during the fall months) which could cause sudden increases in root exudation and lead to increased zoospore activity.

4.2. Container-Grown Seedlings. Neither inoculating seedlings with Pythium species nor wounding seedling roots before storage affected seedling survival. However, as storage length increased, seedling survival decreased for both wounded and nonwounded loblolly, slash, and shortleaf pine seedlings. The root wounding treatment alone affected survival at 6 weeks of storage, and by 12 weeks, wounded and nonwounded seedlings had similar survival $(<8 \%)$. However, Pythiaceous CFUs were recovered more often from seedlings with wounded roots than nonwounded roots. The root wounding treatment was an attempt to simulate the injury of bareroot seedling roots as they are lifted from nursery beds. It is possible that the wounds created (cutting down the sides of the root plug) were able to callus after 6 weeks and not provide an entrance wound for Pythium. Another explanation may be that properties (antagonistic fungi and microbes) in the peat moss-based media suppressed Pythium zoospores [21]. This may explain why higher numbers of Pythiaceous CFUs were recovered but seedling survival was similar to noninoculated seedlings at 12 weeks.

Seedling survival declined after each storage period, but the most pronounced reduction in survival occurred after 12 weeks of storage and was probably due to "time of planting" rather than "storage time." When seedlings are planted beyond the traditional planting season (December-February), droughty soil conditions can result in seedling stress and mortality $[22,23]$. Bareroot seedlings must have time to establish a root system capable of taking up nutrients and water, and in order for this to occur, soil moisture must be adequate at the time of outplanting [23]. In the fall and winter, seedlings usually have time to establish new roots during the cooler, moist months. In our study, reductions in survival after 12 weeks was not due to Pythium inoculation (longleaf, $P=0.6718$, and loblolly, slash, and shortleaf, $P=$ 0.2416 ) but more likely from adverse outplanting conditions, especially since noninoculated seedlings were also affected.

The theory of Pythium infection at lifting from during the fall months may be related to the presence and timing of Pythium zoospore activity and the use of cultural nursery practices (root pruning/undercutting). The fact that poor bareroot seedling survival does not follow lifting and storage in the winter may be due to environmental differences that affect zoospore activity between the two seasons. More research is needed to investigate these theories. Nursery managers that are able to lift and hold seedlings in long-term cold storage in the fall, without the risk of seedling mortality, could possibly ensure the end of the lifting season before spring.

\section{Acknowledgments}

The authors would like to thank the reviewers of the paper for their time and suggestions. Special thanks go to the Southern Forest Nursery Management Cooperative at Auburn University for funding this research and Tommy Hill, Marietjie Quicke, Barry Brooks, and Irene Miller (deceased) for their assistance. They also thank Doug Shelburne at Smurfit-Stone and Wayne Bell and Mike Coyle at International Forest Company for providing seedlings.

\section{References}

[1] L. H. Kahler and A. R. Gilmore, "Field survival of cold stored loblolly pine seedlings,” Tree Planters' Notes, vol. 45, pp. 15-16, 1961.

[2] T. A. Dierauf, "Fall planting and storage using non-dormant seedlings," in Proceedings of the Southeastern Area Nurseryman's Conference-SC Eastern, pp. 31-36, 1976.

[3] J. T. May, Southern Pine Nursery Handbook, USDA Forest Service, Southern Region, 1984.

[4] W. C. Carlson, "Lifting, storing, and transporting southern pine seedlings," in Forest Regeneration Manual, M. L. Duryea and P. M. Dougherty, Eds., chapter 16, Kluwer Academic, Norwell, Mass, USA, 1991.

[5] J. N. Boyer and D. B. South, Dormancy, chilling requirements, and storability of container-grown loblolly pine seedlings, Auburn University, Southern Forest Nursery Management Cooperative Research Note no. 23, 1985.

[6] B. Pickens, "Long-term storage of container longleaf pine," Tech Update, vol. 5, no. 1, p. 1, 1998.

[7] J. P. Barnett, J. C. Brissette, A. G. Kais, and J. P. Jones, "Improving field performance of southern pine seedlings by treating with fungicides before storage," Southern Journal of Applied Forestry, vol. 12, no. 4, pp. 281-285, 1988.

[8] J. P. Jones, D. J. Pantone, J. P. Barnett, and J. C. Brissette, “The relationship between fungal population development and root damage of cold-stored longleaf pine seedlings," Louisiana State University Agricultural Center Bulletin, no. 832, p. 23, 1992.

[9] X. Sun, Biological control of Pythiaceous fungi causing death of longleaf pine seedlings during cold storage, Ph.D. dissertation, Louisiana State University, 1996.

[10] W. D. Kelley and S. W. Oak, "Forest nursery pests," in USDA Forest Service, Agricultural Handbook No. 680, C. E. Cordell, R. L. Anderson, W. H. Hoffard, T. D. Landis, R. S. Smith Jr., and T. V. Harvey, Eds., Tech. Coords., p. 184, 1989.

[11] F. F. Hendrix Jr. and W. A. Campbell, "Pythiums as plant pathogens," Annual Review of Phytopathology, vol. 11, pp. 77-98, 1973.

[12] F. F. Hendrix Jr. and W. A. Campbell, "A new species of $P y$ thium with spiny oogonia and large chlamydospores," Mycologia, vol. 63, pp. 978-982, 1971.

[13] H. H. Ho, "Pythium dimorphum from rhododendron," Mycopathologia, vol. 93, no. 3, pp. 141-145, 1986. 
[14] F. O. Asiegbu, A. Lönneborg, and M. Johansson, "Chitin and glucans detected in the cell walls of Pythium dimorphum-an oomycetous fungus," European Journal of Forest Pathology, vol. 26, no. 6, pp. 315-321, 1996.

[15] A. J. Van der Plaats-Niterink, "Monograph of the Genus Pythium," Studies in Mycology, vol. 21, pp. 242-244, 1981.

[16] C. Linde, G. H. J. Kemp, and M. J. Wingfield, "Pythium irregulare associated with Pinus seedling death on previously cultivated lands," Plant Disease, vol. 78, no. 10, pp. 1002-1005, 1994.

[17] P. L. Lorio, "Phytophthora cinnamomi and Pythium species associated with loblolly pine decline in Louisiana," Plant Disease Reporter, vol. 50, pp. 596-597, 1966.

[18] Y. K. Kim, C. L. Xiao, and J. D. Rogers, "Influence of culture media and environmental factors on mycelial growth and pycnidial production of Sphaeropsis pyriputrescens," Mycologia, vol. 97, no. 1, pp. 25-32, 2005.

[19] Y. Feng and P. H. Dernoeden, "Pythium species associated with root dysfunction of creeping bentgrass in Maryland," Plant Disease, vol. 83, no. 6, pp. 516-520, 1999.

[20] C. L. Campbell and J. P. Noe, "The spatial analysis of soilborne pathogens and root diseases," Annual Review of Phytopathology, vol. 23, pp. 129-148, 1985.

[21] H. Wolffhechel, "The suppressiveness of sphagnum peat to $P y$ thium spp.," Acta Horticulturae, vol. 221, pp. 217-222, 1988.

[22] P. C. Wakeley, "Planting the southern pines," USDA Agricultural Monograph, no. 18, p. 233, 1954.

[23] C. R. Venator, "Survival of shortleaf pine (Pinus echinata Mill.) seedlings as influenced by nursery handling and storage," Tree Planters' Notes, vol. 36, no. 4, pp. 17-19, 1985. 

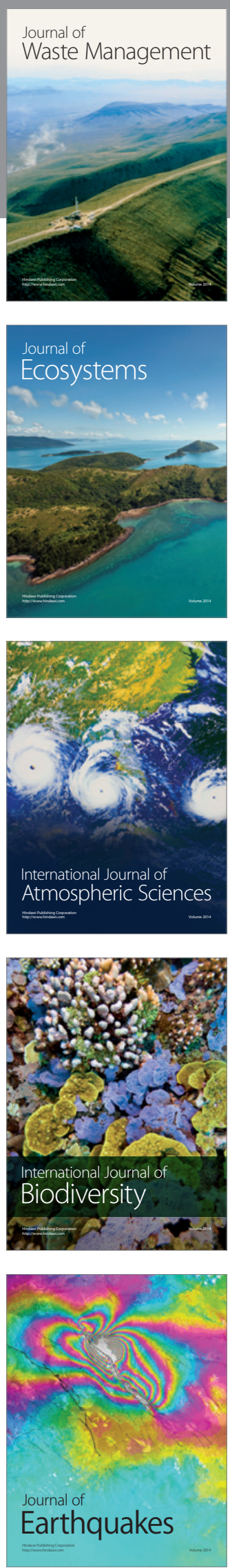
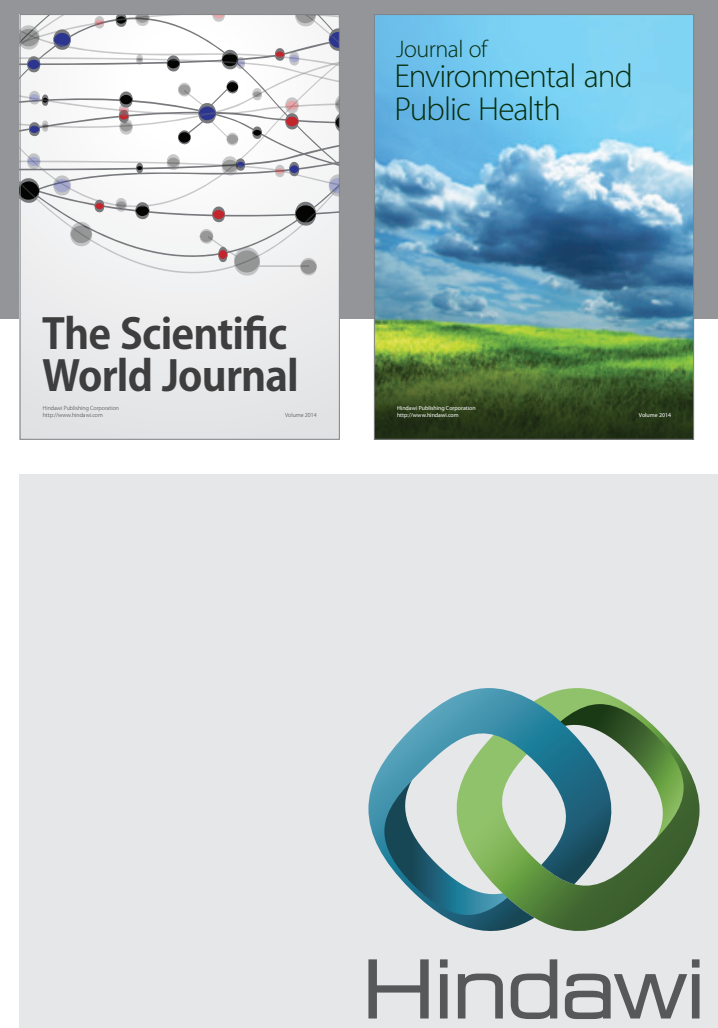

Submit your manuscripts at

http://www.hindawi.com
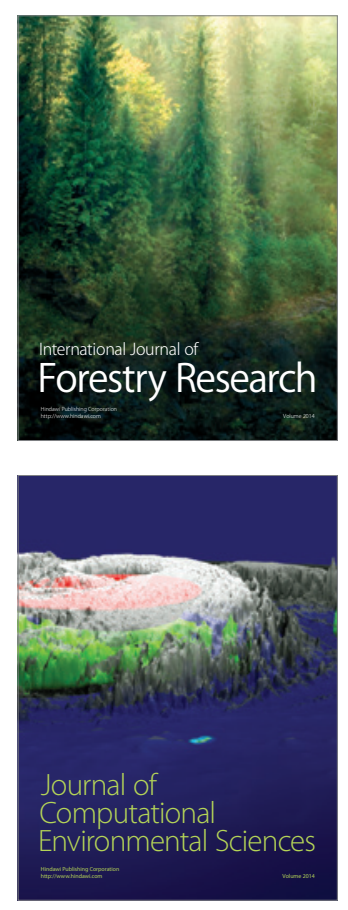
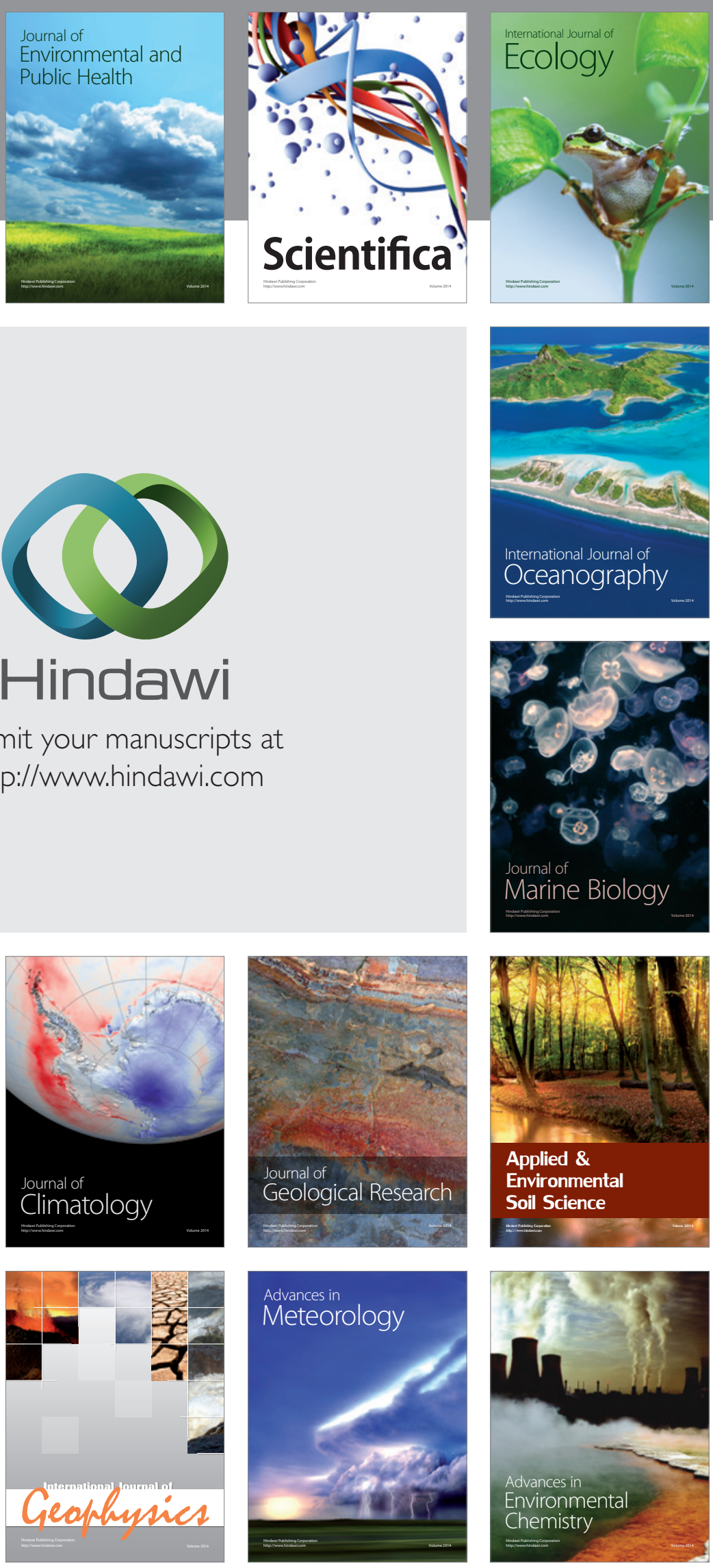